\title{
舌下腺に発生した腺様囊胞癌の一例
}

\author{
和久田幸之助・岡坂 利章・兵 行和 \\ 松永喬
}

\section{Adenoid Cystic Carcinoma of the Sublingual Gland}

\author{
Kounosuke Wakuda, Toshiaki Okasaka, Yukikazu Hyo \\ and Takashi Matsunaga
}

(Nara Medical College)

Biopsy of a sublingual tumor in a 70-year-old female showed adenoid cystic carcinoma. The tumor was resected, and she is alive 10 months after treatment without any evidence of recurrence. Primary malignant tumor of the sublingual gland is extremely rare, with only 67 cases reported in the literature from 1930 to 1984 . The histological types, treatment and prognosis of malignant tumors of the sublingual gland are discussed.

Key words: sublingual tumor, adenoid cystic carcinoma, case report

はじめに

大唾液腺に発生する腫瘍の大部分は耳下腺に みられ，顎下腺に発生する例は少ない。ささらに 舌下腺由来と考えられる腫瘍はきわめて稀であ りそのほとんどが悪性腫瘍であるといわれてい $ろ^{1)}$.

今回, 我々は左口腔底の腫脹を主訴として来 院した70才女性の舌下腺由来腺㥞囊胞癌の一例 を経験したので若干の文献的考察をくわえて報 告する.

\section{症例}

患者: 70才女性.

初診：昭和60年12月23日.

主訴：左口腔底腫脹.

現病歷：約 2 年前, 舌尖のしびれが出現し, 某院内科を受診したが異常なしと言われたため
症状は持続していたが放置していた. 昭和60年 10月頃より, 左口腔底の腫脹に気づいたため, 昭和 60 年 12 月 20 日, 某院耳鼻科を受診し, 唾石 の疑いのため当科を紹介され受診した.

局所所見：口䏶底の腫熘は $2 \times 3 \mathrm{~cm}$, 弾性 硬, 表面は正常口腔粘膜で被われ, 表層の粘膜 および腫瘤底部組織との癒着は認められず可動 性良好であり, 左舌下小丘よりの唾液の排出は 認められた（図 1 )。 な抢, 頸部リンパ節は触 知しなかった。

レントゲン所見：単純撮影, パノラマX線写 真では唾石などを思わせる陰影はなく, 唾液腺 造影では顎下腺開口部より $5 \mathrm{~mm} ゙$ ワルトン氏管 は閉塞していた。胸部 X線は正常.

臨床検查成績: 血液, 尿, 心電図等の検査で 異常は認められなかった。 


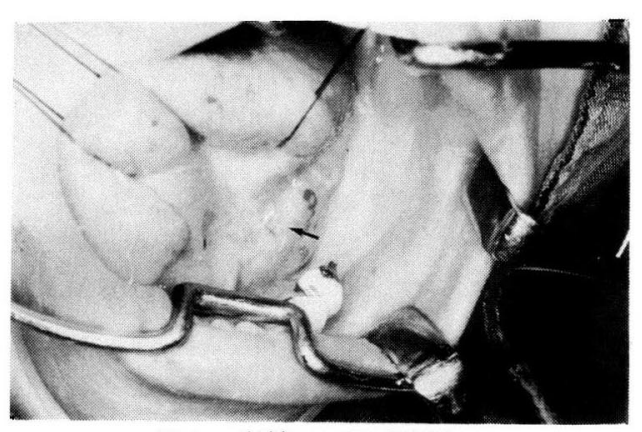

図 I 術前の口腔底所見

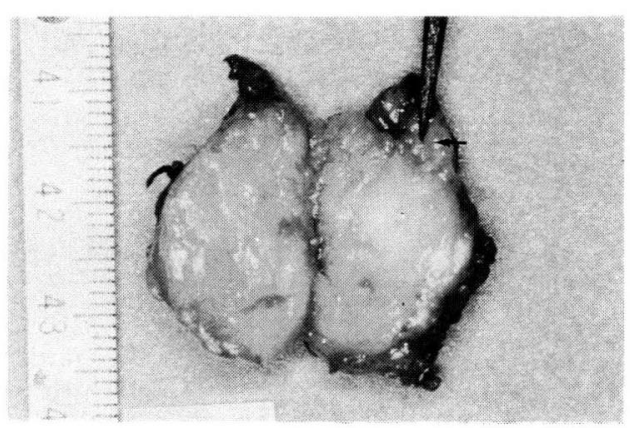

図 2 摘出標本

（指示部はワルトン氏管断端）
臨床診断：口腔底腫瘍.

手術所見：昭和61年 1 月 21 日, 全身林酔下に 腫瘍摘出術を行なった. 左口腔底の腫瘍直上の 粘膜に切開をくわえ，腫瘍と周囲組織を鈍的に 剥離した. 腫瘍は口腔底粘膜と顎舌骨筋の間に 存在し, 内側は舌筋に接しており周囲組織との 瘓着はなく, 腫瘍は被膜に被われ境界鮮明であ った．腫瘍の前および後端に一部索状の部分が

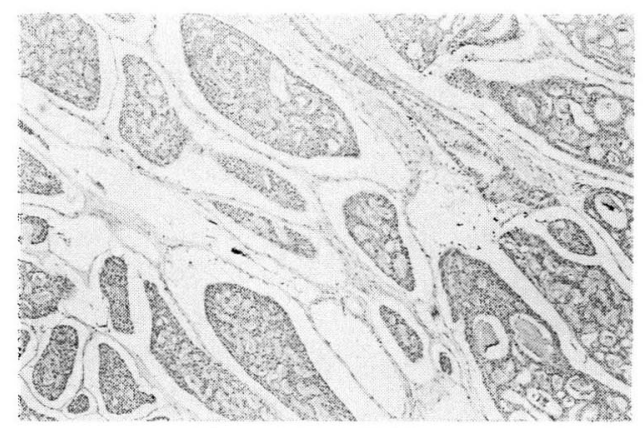

図 3 病理組織所見 定型的な篩状構造を示している.

\section{表 I WH O 分類 ${ }^{7}$}

I. Epithelial tumor

\section{A. Adenomas}

1. Pleomorphic adenomas

2. Monomorphic adenomas
a. Adenolymphoma
b. Oxyphilic adenoma
c. Other types

B. Mucoepidermoid tumor

C. Acinic cell tumor

D. Carcinomas

1. Adenoid cystic carcinoma

2. Adenocarcinoma

3. Epidermoid carcinoma

4. Undifferentiated carcinoma

5. Carcinoma in pleomorphic adenoma (malignant mixed tumor)

II. Non-Epithelial tumors

III. Unclassified tumors

IV. Allied conditions
A. Benign Lymphoepithelial Lesion
B. Sialosis
C. Oncocytosis 
ありワルトン氏管と連絡していて剥離不能であ ったためワルトン氏管を約 $2 \mathrm{~cm}$ 切断し，創部に 開口するように口腔底粘膜に縫合して腫瘍を摘 出した．創部周囲には正常舌下腺は認められ ず, 腫瘍の解剖学的位置関係より舌下腺由来の もの之考えた。摘出した腫瘍は表面平滑, 割 面は乳白色均一の充実性の腫瘍であった（図 2 ). 術後経過は良好で 10 ケ月を経過した現在 も再発の徵候は認められない。

病理組織学的所見：全割切片では腫瘍は被膜 に囲まれていた。全組織内には正常の舌下腺組 織は認められず腫瘍組織におきかわっており， 腫煬は間質に明瞭に境いされ, 各腫煬蜂巣は充

表 3 病理組織分類別頻度

\begin{tabular}{lll}
\hline \hline 腺椂囊胞癌 & 24 例* & $35.3 \%$ \\
粘表皮腫瘍 & 15 & 22.1 \\
多型腺腫由来の癌 & 11 & 16.2 \\
腺癌 & 7 & 10.3 \\
腺房細胞腫瘍 & 5 & 7.4 \\
類表皮癌 & 1 & 1.4 \\
未分化癌 & 1 & 1.4 \\
その他の癌 & 4 & 5.9 \\
\hline
\end{tabular}

*自験例を含む
実性の細胞よりなり, 細胞間には大小の囊胞が 認められ定型的な篩状構造を示し, 腺㥞囊胞癌 と診断した（図3）.

\section{考察}

舌下腺に発生する腫瘍の報告はきわめて少な く全唾液腺腫煌の $0.2 \sim 4.7 \%{ }^{2) \sim 6)}$ と報告されて おり，Rankow ${ }^{11}$ はその $80 \%$ は悪性腫場である と報告している.

唾液腺腫瘍の組織分類としては WHO の分 類7) が広く用いられており，そのB，C，Dが 悪性腫湯とされている（表 1 ).

舌下腺に発生した悪性腫湯は1930年 Brunschwig の報告 ${ }^{8)}$ 以来, 我々が文献的に沙猟し

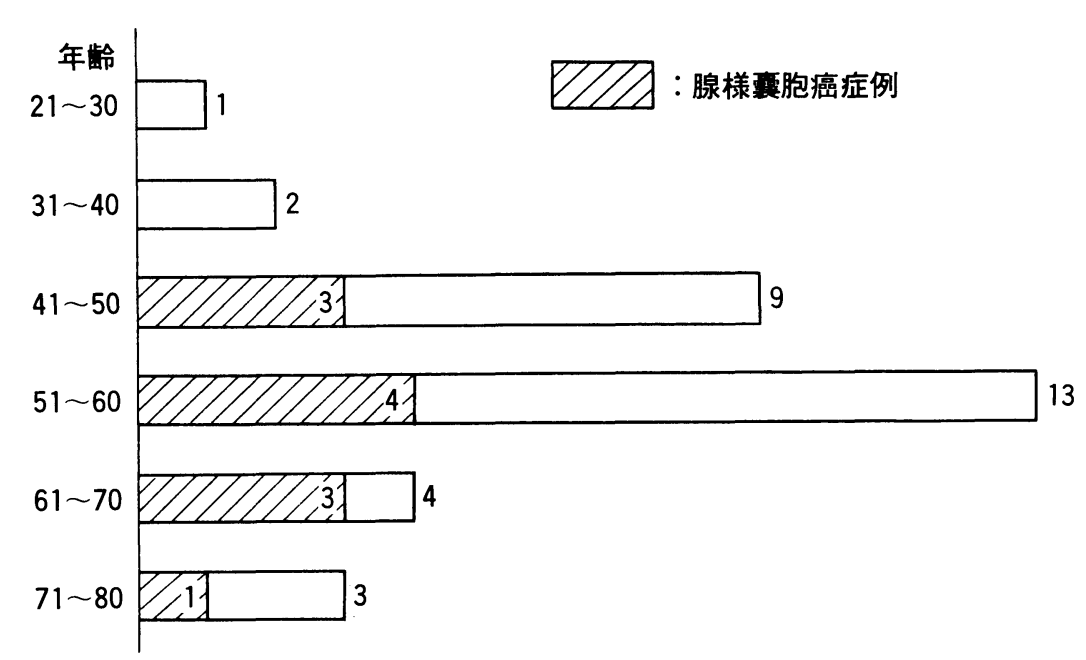

図 4 年柃別頻度

$\begin{array}{lcc}\text { 手術単独 } & \text { 18例（7例 }) \\ \text { 放射線単独 } & 1 & \\ \text { 手術 +放射線 } & 5 & (1) \\ \text { 手術 +放射線+化学療法 } & 2 & (1)\end{array}$

（）は腺様囊胞癌症例 


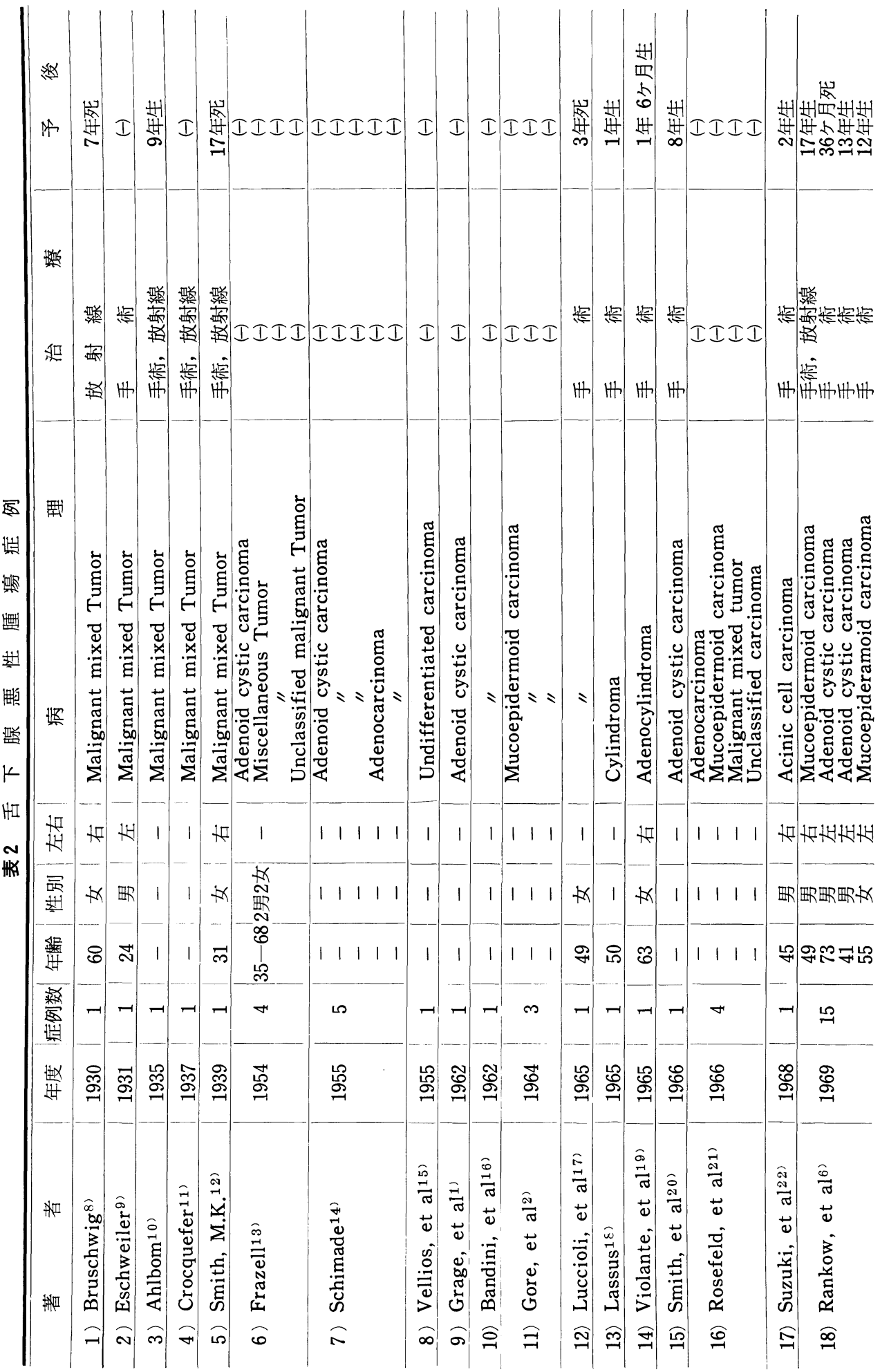




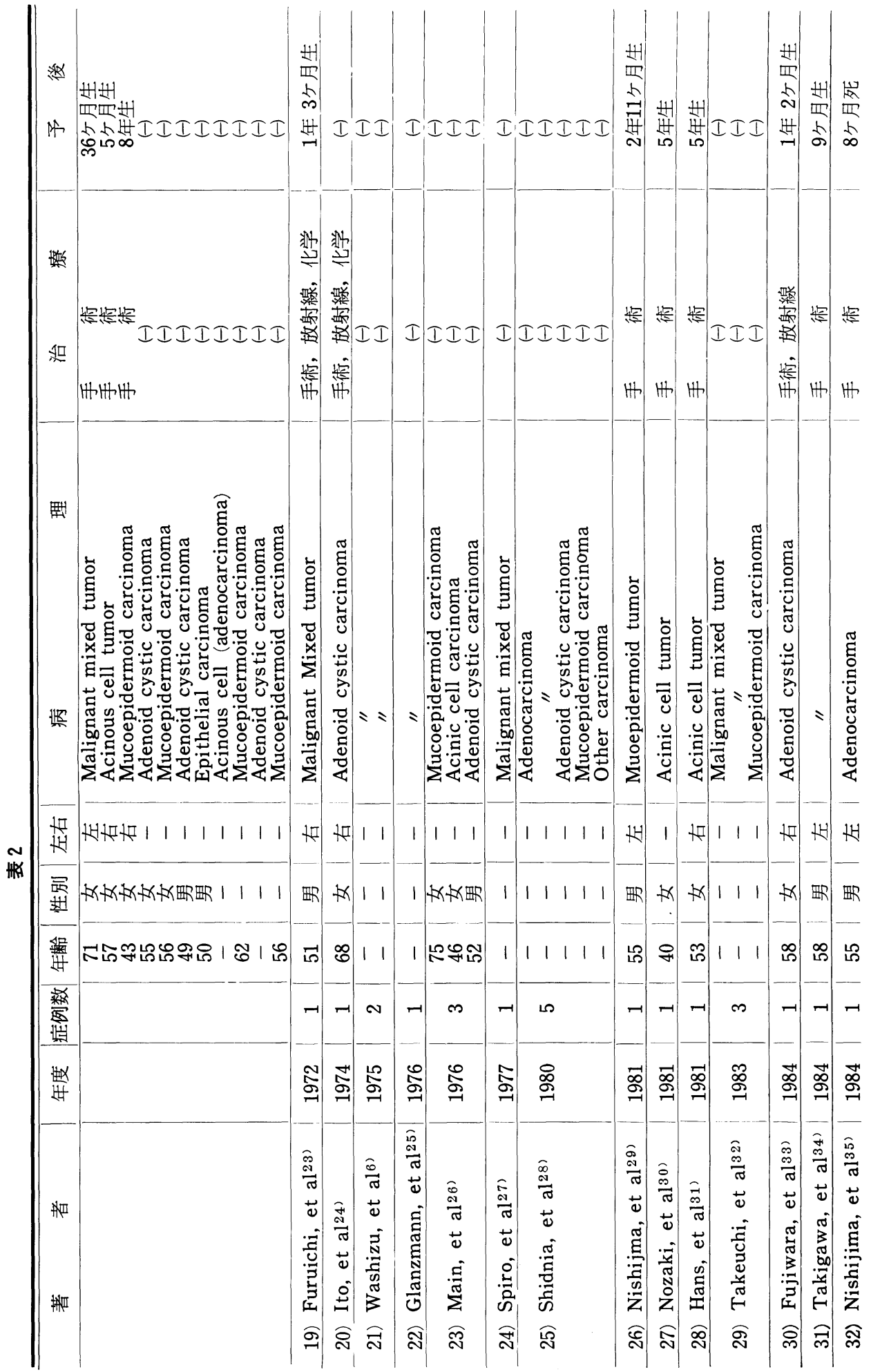


えた症例は自験例を含め68例であった（表 2 ）.

病理組織像を WHO の分類にしたがって 検邻してみる之, 腺様囊胞癌が最も多く24例 (35.3\%)，ついで粘表皮腫煌15例（22.1\%)， 以下悪性混合腫瘍，腺癌の顺になっていた（表 3 ). 腺栐賈胞癌が多い理由として，その正常 腺構造に粘液腺が多いととが一因と考えられ $3^{36)}$.

男女別頻度では男性14例, 女性20例で, 腺様 囊胞癌についてみると男性 5 例，女性 5 例であ り，男女別頻度には差を認めなかった（表 4 ）。

年齢別分布では舌下腺悪性腫瘍は 40 才代, 50 才代に多く認められ, 腺様囊胞癌症例では 40 才 代，50才代，60才代に同頻度に認められた（図 4 ).

治療法では手術単独治療が最屯多く行われて おり，腺㥞囊胞癌症例について文献的に治療法 の部載があった 9 例では，手術療法之放射線療 法を併用した 1 例, 手術・放射線・化学療法を 併用した 1 例を除き，他の 7 例すべて手術単独 治療を行っており，我々も充分な正常組織を含 めた根治的切除が取もよい治療法であると考え ている（表 5 ).

予後について記載された文献22例について考 察してみる之観察期間に長短はあるが死亡例は 5 例であり，1965年以降の報告では 2 例のみで あった. 1 例は腺癌の症例, 他の 1 例は腺様囊 胞癌症例であるが，乙の症例は切除後再発し， この時の治療を拒否しており，また死因屯心疾 患という他因子であった，腺様囊胞癌症例につ いて考えてみるとその予後は適切な治療を行う 事により十分に救命しえる疾患であると思われ る.しかし，その発育は緩徐であり長期にわた って担癌生存することがあり, 5 年生存率が 33 \%であってあ15年後には $80 \%$ が死亡したとの報 告6) 屯あり，長期にわたる観察期間が必要であ ることを強調したい.

\section{まとめ}

左口腔底の腫脹を主訴として来院した 70 才女 性の症例に対し, その腫瘍の解剖学的位置関係
および組織所見より舌下腺由来の腺栐囊胞癌之 診断した。治療は腫瘍の全摘手術を行い, 術後 10ケ月を経過した现在も再発の徵候は認めてい ない。

舌下腺に発生する悪性腫瘍は稀であり，我々 が文献的に考察しえた症例は自験例を含めて 68 例あり，その文献的考察屯あわせて報告した。

なお本論文の要旨は第10回日本頭頸部腫傷学会（於 仙台）において発表した。

\section{文献}

1) Rankow RM and Mignogna F : Cancer of the sublingual salivary gland. Am J Surg II8: 790 795, 1969.

2) Grage TB and Lober PH : Malignant tumors of the major salivary glands. Surgery 52 : 284 294, 1962.

3) Gore DO, Annamunthodo $\mathrm{H}$ and Harland A : Tumors of the salivary gland origin. Surg Gynecol Obstet 1/9:1290 1296, 1964.

4) Castro EB, Huvos AG, Srrong EW, et al : Tumors of the major salivary glands in children. Cancer $29: 312 \sim 317,1972$.

5) Foote FW and Frazell EL: Tumors of the major salivary glands. Cancer $6: 1065 \sim$ 1133, 1953.

6 ）鵟津邦雄：唾液腺腫煌. 頭頸部腫焬図譜（中原和 郎, 竹田千里編). 231 233頁, 中山畫店, 東京, 1975.

7) Thackray AC : Histological typing of salivary gland tumors. WHO, Genave, 1972.

8) Brunschwig A: A mixed tumor of the tongue and sublingual gland. Surg Gynecol Obstet $50: 407 \sim 415,1930$.

9) Eschweiler H : Fall einer Zystisch Veränderten, Malignen Mischgeschwulst der Sublingualdrüse. $Z$ Laryngo Rhinol Otol 22 : 36 39, 1931.

10) Ahlbom HE : Mucous and salivary gland tumors. Acta Radiol Suppl $23:$ 137, 1935.

11) Crocquefer $M:$ Tumeuer mixte dela glande 
sublinguale. Rev Stomatol $39: 896 \sim 898$, 1937.

12) Smith MK : Mixed tumor of the sublingual gland. Ann Surg 109:551 554, 1939.

13) Frazell EL : Clinical aspects of tumors of the major salivary glands. Cancer $7: 637$ $\sim 659,1954$.

14）島田義弘：所謂唾液腺型混合腫煬の組織発生に就 いて. 日病会誌 $44 ： 243 \sim 257,1955$.

15) Vellios $F$ and Davidson $D$ : The natural history of tumors peculiar to the salivary glands. Am J Clin Pathol $25: 147 \sim 157$, 1955.

16) Bandini $\mathrm{A}$ and La Macohia E : Cylindroma of the sublingual gland. Reforma Med 76 : 889, 1962.

17) Luccioli GM, Clement $H$ and Palmer JD : Review article an analysis of 50 carcinoma of the salivary glands. Can J Surg 8 : 389 399, 1965.

18) Lassus $C$ : Sur un cas de Cylindrome de la Glande Sublinguale. Rev Stomatol Palis 66 : 217 218, 1965.

19) Violante E : Adeno-cilindroma della Ghiandola Salivare Sottolinguale. Gior Ital Chir 21:87 96, 1965.

20) Smith LC, Lane N and Rankow RM : Cylindroma (adenoid cystic carcinoma). Am J Strg 110:519 526, 1965.

21) Rossenfeld L, Sessions DG, Meswain B, et al : Malignant tumors of salivary gland origin. Ann Surg 163:726 735, 1966.

22) Suzuki $H$ and Henderson $R$ : Acinic cell carcinma of the sublingual gland. Arch Otolaryngol $87: 146 \sim 149,1968$.

23）古市暢夫, 中島正臣, 及川征一, 他：舌下腺性混 合腫婸の 1 例. 耳崌 $44: 551 \sim 555,1972$.

24）伊東隆利, 水山武彦, 新森 柁, 他: 左側舌下腺 に発生した腺椂囊胞癌の 1 例. 日口外誌 20 ： 315, 1974.

25) Glanzmann C, Aberle HG, Burgener F, et al : Rolle der strahlentherapie bei der Behandlung von Speichel-drusenkarzinomen
(Ergebnisse von 80 Patienten). Strahlentherapie (Germany, West), I52:395 403, 1976.

26) Main JHP, Orr JA, McGurk FM, et al : Salivary gland tumors-review of 634 cases. J Oral Pathol $5: 88 \sim 102,1976$.

27) Spiro RH, Huvos AG and Strong EW : Malignant mixed tumor of salivary origin. Cancer $39:$ 388 396, 1977.

28) Shidnia H, Horngack NB, Hamaker R, et al : Carcinoma of major salivary glands. Cancer $45: 693 \sim 697,1980$.

29）西鴆克己, 小林清司, 松村和良, 他 : 舌下腺部に 発生した粘表皮腫の 1 症例. 口科誌 $30: 264 \sim$ 269, 1981.

30）野崎秋一, 三吉康郎, 坂倉康夫, 他 : 大唾液腺腫 瑝の臨床統計的観察. 耳鼻臨床 $74: 1044 \sim$ 1053, 1981.

31) Van Den Akker HP, Busemann-Sokole E and Becker AE: Acinic cell carcinoma of the sublingual gland. Int J Oral Surg $10: 363$ $\sim 366,1981$.

32) Takeuchi N, Hirose F, Yamamoto $\mathrm{H}$, et al :Salivary gland tumors in atomic bomb survivors, Hiroshima, Japan. II. Pathologic study and supplementary epidemiologic observation. Cancer $52: 377 \sim 385,1983$.

33）藤原康次, 池村邦男：舌下腺に発生した腺様囊胞 癌の 1 例. 日口外誌 $30: 838 \sim 841,1984$.

34）瀧川富雄, 松本光彦, 工藤敏幸, 他: 舌下腺に生 ビたと思われる腺様囊胞癌の 1 例. 日大歯学 58 : 206 210, 1984.

35) Nishijima W, Tokita N, Takooda S, et al : Adenocarcinoma of the sublingual gland. Laryngoscope $94: 96 \sim 101,1984$.

36）宮下久夫：睡液腺一発生・解剖・生理. 臨床耳鼻 咽喉科学 I (沢木修二, 設楽哲也, 野村恭也編). 273 306頁, 中外医学社, 東京, 1976.

原稿採択：昭和 62 年 1 月 9 日 別刷請求先 : 和久田幸之助

于634 奈良県橿原市四條町 840 奈良県立医科大学耳鼻咽喉科学教室 